\title{
ANALISIS PENDAPATAN USAHA PETERNAKAN AYAM BROILER POLA KEMITRAAN DAN POLA MANDIRI DI KECAMATAN KUANTAN TENGAH
}

\author{
Rian Dafitra ${ }^{1}$, Dihan Kurnia ${ }^{2}$, Meli Sasmi ${ }^{3}$ \\ ${ }^{1}$ Mahasiswa Peternakan, ${ }^{2}$ Dosen Program Studi Peternakan, ${ }^{3}$ Dosen Program Studi \\ Agribisnis Fakultas Pertanian Universitas Islam Kuantan Singingi \\ e-mail. dihankurnia5@gmail.com ${ }^{2}, \underline{\text { melisasmi2011@gmail.com }}{ }^{3}$
}

\begin{abstract}
ABSTRAK
Penelitian ini bertujuan untuk menganalisis pendapatan usaha peternakan ayam Broiler pola mandiri dan pola kemitraan di Kecamatan Kuantan Tengah. Penelitian ini dilaksanakan di desa Jake Kecamatan Kuantan Tengah pada bulan Juni sampai bulan Oktober 2018. Metode penelitian yang digunakan metode survey, pemilihan lokasi serta teknik pengambilan sampel secara purposive sampling dan data yang dikumpulkan data primer dan data sekunder. Analisis data yang digunakan adalah analisis matematik. Hasil penelitian menunjukkan bahwa peternak dengan pola mandiri dengan skala 200 ekor dengan biaya keseluruhan atau total biaya yaitu Rp. 6.760.670/periode, dengan total penerimaan yaitu Rp. 6.896.500/periode, dengan total keuntungan yaitu Rp. 135.830/periode, dengan total efisiensi Rp. 1,02/periode artinya satu rupiah biaya yang dikeluarkan maka memperoleh penerimaan sebesar Rp. 1,02 atau keuntungan sebesar Rp. 0,02. Sedangkan peternak dengan pola kemitraan dengan perusahan dengan skala 8.000 ekor dengan biaya keseluruhan atau total biaya yaitu Rp. 214.697.395/periode, dengan total penerimaan yaitu Rp. 230.824.111/periode, dengan total keuntungan yaitu Rp. 16.126.716/periode, dengan total efisiensi Rp. 1,07/periode artinya satu rupiah biaya yang dikeluarkan maka memperoleh penerimaan sebesar Rp. 1,07 atau keuntungan sebesar Rp. 0,07.
\end{abstract}

Kata Kunci : Pendapatan, Ayam Broiler, Pola Mandiri dan Pola Kemitraan

\section{PENDAHULUAN}

Usaha peternakan sekarang ini sudah merupakan suatu usaha yang dapat diandalkan untuk memenuhi kebutuhan hidup keluarga ataupun sebagai usaha yang dapat dikelola secara komersial. Salah satunya peternakan ayam broiler. Dalam Upaya pemenuhan protein hewani dan peningkatan pendapatan peternak, maka berupaya mendayagunakan sumber komoditi ternak yang dikembangkan, diantaranya adalah ayam daging (broiler, hal mendorong peternak yang mengusahakan peternakan ayam broiler.

Pola usaha yang ada pada peternak ayam broiler terbagi menjadi dua, yaitu pola usaha mandiri dan pola usaha kemitraan. Pola kemitraan merupakan suatu bentuk kerja sama antara pengusaha dengan peternak dari segi pengelolaan usaha peternakan. Dalam kemitraan pihak pengusaha dan peternak harus mempunyai posisi yang sejajar agar tujuan kemitraan 
dapat tercapai dimana dalam hal perhitungan tentang biaya produksi diatur sepenuhnya oleh perusahaan yang disepakati bersama oleh peternak.

Sistem peternakan mandiri merupakan sistem usaha beternak dengan modal sepenuhnya ditanggung peternak. Peternak menyediakan kandang, peralatan, tenaga kerja dan sarana produksi ternak DOC, pakan serta memasarkan sendiri ternaknya baik ternak hidup maupun dalam bentuk karkas. Karena keseluruhan modal sendiri maka peternak mandiri sulit dalam pengembangan usaha, pemasaran sulit dalam jumlah besar, dan untuk resiko juga ditanggung sendiri oleh peternakan mandiri.Berdasarkan permasalahan tersebut maka penulis tertarik melakukan penelitian tentang " Analisis pendapatan usaha peternakan ayam broiler pola kemitraan dan pola mandiri di Kecamatan Kuantan Tengah".

\section{METODE PENELITIAN}

\section{Waktu Dan Tempat Penelitian}

Penelitian ini telah dilaksanakan selama 4 bulan mulai pada bulan Juni 2018 sampai bulan Oktober 2018 bertempat di Desa Jake Kecamatan Kuantan Tengah Kabupaten Kuantan Singingi.

\section{Metode Penentuan Sampel}

Pengambilan sampel dilakukan dengan metode survai dengan purposive sampling (secara sengaja) terhadap 2 orang responden pada masing-masing usaha
Peternakanayam Broiler Pola mandiri dan Kemitraan. Desa dan kecamatan yang dipilih dengan alasan bahwa di Desa Jake Kecamatan Kuantan Tengah terdapat usaha peternakan ayam broiler dengan pola mandiri dan kemitraan.

Pemilihan sampel dilakukan terhadap peternak yang melakukan usaha secara mandiri dan kemitraan secara purposive dengan alasan kedua peternak tersebut secara kontinyu melakukan usaha peternakan ayam broiler dan lebih mudah mendapatkan informasi dan data tentang usaha tersebut.

\section{Jenis dan Sumber Data}

Jenis data yang digunakan dalam penelitian ini adalah data primer dan data sekunder. Data primer berasal dari pengamatan langsung, wawancara dengan peternak dengan pengisian kuisioner yang telah disiapkan, adapun data yang diperlukan meliputi umur responden, pendidikan, pengalaman beternak, biaya, produksi, serta hal - hal yang berhubungan dengan penelitian.

Data sekunder merupakan data yang diambil langsung dari Instansi terkait, seperti data populasi, dan produksi ayam broiler, profil daerah penelitian, dan lain-lain yang dibutuhkan dalam menunjang penelitian.

\section{Metode Analisis Data}

Metode analisis data yang digunakan adalah metode deskriptif dan 
metode kuantitatif. Untuk menjawab $\mathrm{R} / \mathrm{C}=$

TR

/TC tujuan dilakukan analisis data dengan menghitung tingkat pendapatan dan efisiensi usaha peternakan pola mandiri dan pola kemitraan dengan dianalisis secara matematika.

\section{Analisis Pendapatan}

Menurut widjaya (1998) persamaan keuntungan $(\pi)$ dapat ditulis sebagai berikut:

$\pi \quad=\mathrm{TR}-\mathrm{TC}$

$=\mathrm{TR}-(\mathrm{TFC}+\mathrm{TVC})$

$\mathrm{TR}=\mathrm{Y} 1 . \mathrm{Py} 1+\mathrm{Y} 2 \cdot \mathrm{Py} 2+$ Y3.Py3.

$\mathrm{TC}=\quad \mathrm{TFC}+\mathrm{TVC}$

Dimana :

$$
\begin{array}{ll}
\Pi & =\text { Keuntungan } \\
\mathrm{TR} & =\text { Total penerimaan } \\
\mathrm{Py} & =\text { Harga produksi } \\
\mathrm{Y} & =\text { Produksi yang diperoleh }
\end{array}
$$

dari suatu usaha

$$
\begin{array}{ll}
\text { TC } & =\text { Total Cost } \\
\text { TFC } & =\text { Total Fixed Cost } \\
\text { TVC } & =\text { Total Variabel Cost }
\end{array}
$$

\section{Analisis Efisiensi Usaha (R/C)}

Dimana :

$$
\mathrm{R} / \mathrm{C}>1 \text {, Usaha efisien }
$$

$\mathrm{R} / \mathrm{C}<1$, Tidak Efisien.

$\mathrm{R} / \mathrm{C}=1, \mathrm{BEP}$

\section{HASIL DAN PEMBAHASAN}

\section{Sistem Pola Mandiri dan Kemitraan}

Bentuk usaha dengan pola mandiri merupakan sistem usaha beternak dengan modal sepenuhnya ditanggung peternak. Peternak menyediakan kandang, peralatan, tenaga kerja, sarana produksi ternak DOC, pakan serta memasarkan sendiri ternaknya.

Pola kemitraan dengan perusahaan merupakan suatu bentuk kerja sama antara pengusaha dengan peternak dari segi pengelolaan usaha peternakan. Dalam kemitraan pihak pengusaha dan peternak harus mempunyai posisi yang sejajar agar tujuan kemitraan dapat tercapai dimana dalam hal perhitungan tentang biaya produksi diatur sepenuhnya oleh perusahaan yang disepakati bersama oleh peternak pemasaran lansung oleh perusahaan.

\section{Pendapatan dan Efisiensi Usaha}

\section{Peternakan Ayam Broiler}

Pendapatan peternak ayam broiler pada dua pola yaitu Pola mandiri dan pola mitra memiliki perbedaan keuntungan dan nilai efisiensinya. Hal ini disebabkan oleh 
beberapa faktor yaitu 1) jumlah populasi, $\quad$ Secara rinci dijelaskan pada Tabel 1. harga produksi serta biaya produksi.

Tabel 1. Pendapatan dan Tingkat Efisiensi Peternakan Ayam Broiler pada Pola Mandiri dan Kemitraan.

\begin{tabular}{clcccc}
\hline No & Uraian & Penerimaan $(\mathrm{Rp})$ & Total Biaya $(\mathrm{Rp})$ & $\begin{array}{c}\text { Keuntungan } \\
(\mathrm{Rp})\end{array}$ & Efisiensi \\
\hline 1 & \multicolumn{1}{c}{2} & \multicolumn{1}{c}{3} & 4 & $5=3-4$ & $6=3 / 4$ \\
\hline 1 & Pola Mandiri & 6.895 .500 & 6.760 .670 & 135.830 & 1,02 \\
2 & $\begin{array}{l}\text { Pola } \\
\text { Kemitraan }\end{array}$ & 230.824 .111 & 214.697 .395 & 16.126 .716 & 1.07 \\
& & & & \\
\hline
\end{tabular}

Dari Tabel 1. Terlihat tingkat keuntungan terbesar berada pada pola kemitraan hal ini disebabkan karna lebih besarnya sakala usaha dibandingan dengan pola mandiri. Pada Pola kemitraan jumlah populasi sebanyak 8000 ekor sedangkan pada pola Mandiri hanya sebanyak 200 ekor, Sesuai dengan pendapat Gusasi dan Saade (2006), bahwa perbedaan pendapatan pada setiap tingkatan skala usaha sangat nyata sehingga manfaat dan keuntungan dapat diperoleh pada skala usaha yang lebih besar.

Nilai efisiensi pada pola mandiri dan kemitraan mmiliki perbedaan yaitu pada pola mandiri sebesar 1,02 hal ini menunjukkan bahwa setiap biaya yang dikeluar 1 rupiah maka memperoleh penerimaan sebesar 1,02 rupiah atau memperoleh keuntungan sebesar 0,02 rupiah. Pada pola kemitraan memiliki nilai efisiensi sebesar 1,07 hal ini berarti setiap 1 rupiah biaya yang dikeluarkan memperoleh penerimaan sebesar 1,07 rupiah atau keuntungan sebesar 0,07 rupiah. Selisih keuntungan pada nilai efisiensi kedua pola tersebut sebesar 0.05 rupiah.

\section{Penerimaan Hasil Produksi}

Total penerimaan usaha peternakan ayam broiler secara rinci dijelaskan pada Tabel 2.

Tabel 2. Penerimaan Usaha Peternakan ayam Broiler Pola Mandiri dan Pola Kemitraan

\begin{tabular}{|c|c|c|c|c|c|c|}
\hline No & Jenis Pola Usaha & $\begin{array}{l}\text { Skala } \\
\text { Usaha }\end{array}$ & $\begin{array}{l}\text { Produksi } \\
\text { (unit) }\end{array}$ & Satuan & $\begin{array}{c}\text { Harga } \\
(\mathrm{Rp} / \mathrm{Kg})\end{array}$ & Penerimaan $(\mathrm{Rp})$ \\
\hline \multirow[t]{4}{*}{1} & Mandiri & & & & & \\
\hline & - Ayam Potong & 200 & 347 & $\mathrm{~kg}$ & 19.500 & 6.776 .500 \\
\hline & - Kotoran ayam & & 300 & $\mathrm{~kg}$ & 400 & 120.000 \\
\hline & - Karung pakan & & 10 & lembar & 1000 & $\begin{array}{c}10.000 \\
\mathbf{6 . 8 9 6 . 5 0 0}\end{array}$ \\
\hline \multirow[t]{2}{*}{2} & Kemitraan & 8000 & & & & \\
\hline & - Ayam Potong & & 11.490 & $\mathrm{~kg}$ & 16.605 & 224.003 .111 \\
\hline
\end{tabular}


- Kotoran ayam

$16.000 \quad \mathrm{~kg} \quad 400$

6.400 .000

- Karung pakan

Berdasarkan Tabel 2 terlihat bahwa

penerimaan terbesar terdapat pada pola kemitraan yaitu sebesar Rp.230.824.111,sedangkan usaha pada pola mandiri sebesar Rp.6.896.500,-. Besarnya penerimaan pada pola kemitraan tersebut dipengaruhi oleh beberapa hal, yaitu jumlah populasi ayam broiler jauh lebih banyak dibandingkan dengan pola mandiri, jumlah kotoran ayam dan karung lebih banyak sehingga dapat mempengaruhi besarnya penerimaan.

\section{Biaya Produksi}

Biaya produksi pada usaha peternakan ayam broiler pola mandiri merupakan biaya yang dikeluar dalam satu kali proses produksi yang terdiri dari biaya tetap dan tidak tetap. Terlihat pada kedua pola usaha peternakan ayam broiler, biaya produksi terbesar terdapat pada pola kemitraan hal ini secara rinci dapat dijelaskan Tabel 3.

Tabel 3. Biaya Produksi Usaha Peternakan Ayam Broiler Pola Mandiri dan Kemitraan

\begin{tabular}{|c|c|c|c|c|c|c|c|}
\hline No & $\begin{array}{c}\text { Jenis Pola } \\
\text { Usaha }\end{array}$ & $\begin{array}{c}\text { Biaya } \\
\text { Tetap (Rp) }\end{array}$ & $\%$ & $\begin{array}{c}\text { Biaya Tidak } \\
\text { Tetap } \\
\text { (Rp) }\end{array}$ & $\%$ & $\begin{array}{l}\text { Total Biaya } \\
\text { (Rp) }\end{array}$ & $\%$ \\
\hline 1 & Mand & 195. & 4,836 & 6.565 .000 & 3,017 & 670 & 3,053 \\
\hline 2 & Kemitra & 3.850 & $\begin{array}{r}95,16 \\
4\end{array}$ & 210.847 .215 & $\begin{array}{r}96,89 \\
3\end{array}$ & 395 & $\begin{array}{l}96,94 \\
7\end{array}$ \\
\hline & TOTAL & 4.045 .850 & $\begin{array}{r}100,0 \\
0\end{array}$ & 217.607 .885 & $\begin{array}{r}100,0 \\
0\end{array}$ & 221.458 .065 & $\begin{array}{l}100,0 \\
0\end{array}$ \\
\hline
\end{tabular}

Terlihat dari kedua pola ternyata biaya penyusutan kandang atau biaya investasi yang terbesar. Penyusutan kandang pada pola kemitraan lebih besar dibanding pola mandiri dikarenakan pada pola kemitatraan jauh lebih besar karna populasi ayam juga banyak sehingga dibutuhkan kandang sesuai standar secara teknis. Perlunya manajemen kandang secara teknis sebagai upaya untuk melindungi ternak dari kepadatan kandang dan terhidar dari stress. Sesuai pendapat Hardjosworo dan Rukmiasih (2000).

Besarnya biaya investasi kandang dalam usaha peternakan menyebabkan peternak mandiri mengalami kesulitan memperluas skalanya,padahal harga penjualan berpotensi mendapatkan keuntungan yang lebih besar. Perlunya ketersediaan modal dengan melakukan 
kerjasama lembaga keuangan dalam memberikan kredit lunak seingga dapat memotifasi dalam mengembangkan usahanya dan dapat mengurangi ketergantungan produksi ayam broiler dari dari luar.

Kebutuhan pakan merupakan biaya terbesar pada biaya tidak tetap hal ini terlihat jumlah kebutuhan pakan sangat menentukan peningkatan bobot dan keuntungan serta efisiesi biaya pakan. Besarnya perbandingan antara bobot ayam broiler dengan pakan yang dihabiskan dihitung berdasarkan nilai Compersi dapat dijelaskan pada Tabel 4.

Tabel 4. Besarnya kebutuhan pakan terhadap Peningkatan Bobot Dalam satuan kilo.

\begin{tabular}{cllccccc}
\hline No & Jenis Pola & $\begin{array}{c}\text { Skala Usaha } \\
(\text { ekor })\end{array}$ & $\begin{array}{c}\text { Produksi/Bobot } \\
(\mathrm{kg})\end{array}$ & $\begin{array}{c}\text { Rata-rata } \\
\text { Bobot }(\mathrm{kg})\end{array}$ & $\begin{array}{c}\text { Comsumsi } \\
\text { Pakan } \\
(\mathrm{kg})\end{array}$ & $\begin{array}{c}\text { Nilai } \\
\text { konversi }\end{array}$ \\
\hline 1 & \multicolumn{1}{c}{2} & \multicolumn{1}{c}{3} & \multicolumn{1}{c}{4} & $5=4 / 3$ & 6 & $7=6 / 4$ \\
\hline 1 & Mandiri & 200 & 347 & 1,735 & 500 & 1,441 \\
2 & Kemitraan & 8.000 & 13.490 & 1,686 & 21.075 & 1,562 \\
\hline
\end{tabular}

Pada Tabel 4 dapat dijelaskan bahwa rata-rata bobot ayam pada pola mandiri sebesar 1,375 jika dianggap tidak ada anggka mortalitas dengan populasi sebanyak 200 ekor, sedangkan pada pola kemitraan dengan jumlah populasi 8.000 ekor seberat $1,686 \mathrm{~kg}$. Sedangkan dari hasil penelitian diperoleh nilai Compersi pada pola mandiri sebesar 1,441 , yang artinya : setiap kenaikan bobot ayam $1 \mathrm{~kg}$ memerlukan pakan seberat $1,441 \mathrm{~kg}$. Pada pola kemitraan nilai compersi sebesar 1,562 , artinya setiap kenaikan bobot ayam $1 \mathrm{~kg}$ memerlukan pakan seberat $1,562 \mathrm{~kg}$. Atau pada pola mandiri setiap $1 \mathrm{~kg}$ pakan yang dihabiskan mampu meningkatkan bobot badan seberat $0,694 \mathrm{~kg}$, sedangkan pada pola kemitran setiap $1 \mathrm{~kg}$ pakan yang dihabiskan mampu meningkatkan bobot badan seberat $0,640 \mathrm{~kg}$.

\section{KESIMPULAN DAN SARAN}

\section{Kesimpulan}

Berdasarkan hasil penelitian yang telah dilakukan dapat disimpulkan bahwa:

1. Tingkat pendapatan usaha peternakan ayam broiler pola mandiri sebesar Rp. 135.830,-, dengan total biaya yang dikeluarkan sebesar Rp. 6.760.670,-sedangkan pada pola kemitraan sebesar Rp. 16.126.716,, dengan total biaya sebesar Rp. 214.697.395,-

2. Tingkat efisiensi usaha pada pola mandiri dan mitra $\mathrm{R} / \mathrm{C}>1$ yaitu pada pola mandiri sebesar 1,020 , artinya setiap biaya yang dikeluarkan satu rupian maka 


\section{Saran}

memperoleh penerimaan sebesar 1,020 rupiah atau memperoleh keuntungan sebesar 0,02 rupiah. Pada pola kemitraan sebesar 1,075, artinya setiap biaya yang dikeluarkan satu rupian maka memperoleh penerimaan sebesar 1,075 rupiah atau memperoleh keuntungan sebesar 0,07 rupiah.

1. Untuk meningkatkan keuntungan pada pola mandiri maka peternak harus memperbesar skala usahanya dan membuat pakan alternatif atau menghemat biaya pakan.

3. Perlunya pemerinta dan lembaga keuangan membantu peternak dalam memperoleh modal usaha agar dapat mengembangkan usaha peternakan secara mandiri

4. Perlunya perbaikan perjanjian kontrak antara peternak dan mitra usaha untuk menetapkan harga penjual dengan mengikuti harga pasar.

\section{DAFTAR PUSTAKA}

Boediono. 1996. Ekonomi Moneter, Seri Sinopsis Pengantar Ilmu Ekonomi. Yogyakarta: BPFE.

Fadilah, et al. 2004. Ayam Broiler Komersial. Agromedia Pustaka, Jakarta.

Garrison, H. Ray; Eric W. Noreen; dan Peter C. Brewer. 2006, AkuntansiManajerial,(terjemahan: A. Totok Budisantoso), Buku I, Edisi Kesebelas,Penerbit : Salemba Empat, Jakarta.

Godfrey, J., A. Hodgson, S. Holms , dan A. Tarca. 2010. Accounting Theory. John Wiley \& Sons: Australia.

Gutama, I.B, K. 2000. Pola Kemitraan Antara Petani Jahe Gajah Dengan Perusahaan Jahe Asinan di Kabupaten Bangli. Skripsi. Jurusan Sosek Pertanian UNUD: Denpasar.

Hardjosworo dan Rukmiasih, M. S. 2000. Meningkatkan Produksi Daging. Penebar Swadaya, Yogyakarta.
Linton, I., 1997. Kemitraan Meraih Keuntungan Bersama. Jakarta : Hailarang. Priyatno. 2000. Mendirikan Usaha Pemotongan Ayam. Penebar Swadaya. Jakarta.

Rasyaf, M. 2004. Pengolahan Usaha Peternakan Ayam Pedaging. Cetakan ke-2 Penebar Swadaya, Jakarta.. 2006. Beternak Ayam Pedaging. Penebar Swadaya. Jakarta.

Salam, T.,dkk. 2006. Analisis Finansial Usaha Peternakan Ayam Broiler Pola Kemitraan. Jurnal Agrisistem, Juni 2006, Vol.2, No.1.

Saragih, B. 2000. Kumpulan Pemikiran: Agribisnis Berbasis Peternakan. CetakanKedua. Pustaka Wirausaha Muda. PT. Loji Grafika Griya Sarana, Bogor.

Sarwanto, C., 2004. Kemitraan Produksi Dan Pendapatan Peternak Ayam Ras Pedaging Di Kabupaten Karang Anyar Dan Sukoharjo [tesis]. Bogor. Fakultas Pertanian, IPB.

Susilorini. 2000. Budi daya 22 Ternak Potensial. Penebar Swadaya. Jakarta.

Tohar. 2000. Membuka Usaha Kecil. Yogyakarata : Kanisius.

Yemima. 2014. Analisis Usaha Peternakan Ayam Broiler pada Peternakan.

Yulianti F 2012. Kajian Analisis Pola Usaha Pengembangan Ayam Broiler di Kota Banjarbaru. Jurnal Ilmu-ilmu Sosial 4(1):65 - 72 . 